\title{
Effect of Acid Treatment on the Chemical Properties of Clays from Selected Sites in Murang'a and Nyeri counties, Kenya
}

\author{
Hassan M. Lomertwala*, Peter W. Njoroge, Sylvia A. Opiyo, Brian M. Ptoton \\ Department of Physical and Biological Sciences, Murang'a University of Technology \\ P.O BOX 75-10200, Murang'a, Kenya
}

\begin{abstract}
Assessing improvement on the quality of clay has been conducted by treatment with different concentrations of hydrochloric and oxalic acid. This project intended to assess the effect of acid treatment on the elemental composition of clays from selected sites. The clays were leached using hydrochloric and oxalic acid separately at a concentration of $0.0,0.1,0.25,0.5,1$, and $2 \mathrm{M}$. The elemental composition of raw and acid-treated clays was determined using AAS. Elemental composition of the acid-treated clays, in oxide form were in the ranges of 40.80$65.16 \% \mathrm{SiO}_{2}, 7.16-30.33 \% \mathrm{Al}_{2} \mathrm{O}_{3}, 0.33-7.62 \% \mathrm{TiO}_{2}, 0.24-2.65 \% \mathrm{~K}_{2} \mathrm{O}, 0.01-1.82 \% \mathrm{MgO}$. The findings of this study showed that the quality of clays could be improved by acid treatment hence the clays can be used as a source of raw materials for industrial applications.
\end{abstract}

Keywords: Acid-treatment, Elemental, raw materials

DOI: $10.7176 / J N S R / 11-22-05$

Publication date: November $30^{\text {th }} 2020$

\section{Introduction}

Clay is a stony or earthy mineral aggregate composed of fine-grained minerals, which are plastic at appropriate water content and hardens up when fired [1,2]. Clays have a variable chemical composition that largely depends on parent rock from which they originated and the physical and chemical changes in the environment where they are found [3]. Clay has silica, alumina ,and water as primary constituents; other constituents are iron, alkaline, and alkaline earth metals [4]. The industrial utilization of clay is closely related to its reactivity and surface properties and depends strongly on surface modification. Several ways are recommended in literature to enhance the properties of clay materials with thermo-chemical treatment [5, 6] or chemical activation [7].

The presence of built-in impurities in clays has a huge impact on the utility of clays, Most clays contain high levels of iron oxides, acid treatment help improve properties and applications of clay [5,8]. Iron impurities removal and reduction are of great importance for the usability of clay in many of its applications especially where purity requirements are specifically high, in order to make high-quality ceramic products clay with low iron content, preferably less than 1\% are desirable [9]. Approaches of minimizing iron in clays include froth floatation, gravity, and magnetic separation, reductive roasting, size separation by hydrocyclone, selective flocculation and acid treatment/leaching $[10,11,12,13,14,15]$. Chemical treatment methods such as acid activation improve surface and catalytic properties of clay by inducing changes in crystal structures of aluminosilicate minerals because of the dissolution of ions and/or structural rearrangement $[16,10,5,8]$. Hydrochloric acid is preferentially used because of the ease of titration of its slurry, ease of removal of the iron matrix, and titanium oxide insolubility, which is present in many types of clay [17]. However, other inorganic acids used include sulfuric acid [13, 14, 12]. Among the organic acids, Oxalic acid has shown the best efficiency in kaolin whitening with iron removals of 45$80 \%$ having been obtained [18]. [14] Studied iron removal from clays by acid treatment, the findings of the study revealed that plasticity property of the acid-treated clays was restored by base treatment of the acid-treated samples [14]. [15] Studied elemental and mineralogical composition of raw and acid-washed clays from Kano plains, the findings of this study revealed that iron oxides levels were reduced by acid treatment and the second finding was that acid treatment alters the mineralogical composition of clays and results to clay minerals interconversion [15].

This study was conducted with the aim of assessing the effect of treating clays with different concentrations of hydrochloric and oxalic acid on the elemental composition of clays. This paper, therefore, reports the findings of the effects of acid treatment on the elemental composition of acid-treated clays.

\section{Materials and Methods}

The purposive non-probability sampling design was used to select sampling sites. Samples were obtained from sites whose clays were being used commercially for pottery. The clay deposits investigated were collected from Githima $\left(0^{\circ} 46^{\prime} 40^{\prime \prime} \mathrm{S}, 37^{\circ} 6^{\prime} 31^{\prime \prime} \mathrm{E}\right)$, Kimathi $\left(0^{\circ} 40^{\prime} 0^{\prime \prime} \mathrm{S}, 37^{\circ} 10^{\prime} 28^{\prime \prime} \mathrm{E}\right)$ and Ithanje $\left(0^{\circ} 36^{\prime} 30^{\prime \prime} \mathrm{S}, 37^{\circ} 6^{\prime} 46^{\prime \prime}\right.$ E). The clay samples were collected at two depths that is 0.5 and 1.0 meter. In each site, the clay samples were obtained from three (3) points that were at least 100 meters apart. From each sampling point/depth $10 \mathrm{~kg}$ samples were collected and packed in newly cleaned plastic buckets which were then covered with their lids.

Weighed $0.1 \mathrm{~g}$ of clay sample was placed in a $125-\mathrm{mL}$ plastic beaker, $1.0 \mathrm{ml}$ of aqua-regia was added then 3.0 $\mathrm{ml}$ of hydrofluoric acid was added and left to digest for 8 hours. $50 \mathrm{ml}$ boric acid was added to allow further 
digestion for one hour. This solution was topped to the $100 \mathrm{ml}$ mark using distilled water. Samples were analyzed alongside the standards [13]. This was done using AAS at the department of Mines and Geology, Ministry of Petroleum and Mining. The results of the elemental analysis of the raw clay samples were given in the form of percentage weight (wt \%) of $\mathrm{SiO}_{2}, \mathrm{Al}_{2} \mathrm{O}_{3}, \mathrm{Fe}_{2} \mathrm{O}_{3}$, etc.

Weighed $100 \mathrm{~g}$ of each sample was put in a beaker and $200 \mathrm{ml}$ of hydrochloric acid of different molarities $(0.0 \mathrm{M}, 0.1 \mathrm{M}, 0.25 \mathrm{M}, 0.5 \mathrm{M}, 1 \mathrm{M}$, and $2 \mathrm{M})$ was added to each clay sample and the reaction allowed to proceed for 24 hours. Each of the mixtures obtained was subjected to filtration and the residue washed using distilled water to remove any acid-matrix. Rinsed residues were oven-dried then later cooled. The cooled samples were prepared for AAS analysis $[3,13]$.

\section{Results and Discussion}

Table 1 below shows variation in concentration of the various elements when the clays samples were treated with different concentrations of hydrochloric and oxalic acid.

Table 1: Variation of the elemental composition of clays from selected sites with acid treatment

\begin{tabular}{|c|c|c|c|c|c|c|c|c|c|c|c|}
\hline \multirow[b]{2}{*}{$\begin{array}{l}\text { Acid } \\
\text { used }\end{array}$} & \multirow[b]{2}{*}{ Site } & \multirow[b]{2}{*}{$\begin{array}{l}\text { Acid } \\
\text { conc }\end{array}$} & \multicolumn{8}{|c|}{ *Elemental composition $(\%)$} & \multirow[b]{2}{*}{ LOI } \\
\hline & & & $\mathrm{SiO}_{2}$ & $\mathrm{Al}_{2} \mathrm{O}_{3}$ & $\mathrm{CaO}$ & $\mathrm{MgO}$ & $\mathrm{K}_{2} \mathrm{O}$ & $\mathrm{TiO}_{2}$ & $\mathrm{MnO}$ & $\mathrm{Fe}_{2} \mathrm{O}_{3}$ & \\
\hline \multirow{18}{*}{$\begin{array}{l}\mathrm{HCl} \\
\text { acid }\end{array}$} & \multirow[t]{6}{*}{ Githima } & $0.0 \mathrm{M}$ & $40.80 \pm 0.06$ & $16.27 \pm 0.05$ & $0.56 \pm 0.04$ & $0.02 \pm 0.01$ & $0.96 \pm 0.03$ & $7.62 \pm 0.03$ & $0.08 \pm 0.02$ & $20.53 \pm 0.15$ & 11.47 \\
\hline & & $0.1 \mathrm{M}$ & $42.34 \pm 0.44$ & $16.01 \pm 0.24$ & $0.55 \pm 0.08$ & $0.02 \pm 0.01$ & $0.94 \pm 0.14$ & $7.59 \pm 0.59$ & $0.08 \pm 0.03$ & $19.56 \pm 0.62$ & 12.24 \\
\hline & & $0.25 \mathrm{M}$ & $44.27 \pm 0.56$ & $14.56 \pm 0.23$ & $0.42 \pm 0.04$ & $0.02 \pm 0.01$ & $0.86 \pm 0.12$ & $7.18 \pm 0.20$ & $0.07 \pm 0.02$ & $18.14 \pm 0.45$ & 13.17 \\
\hline & & $0.5 \mathrm{M}$ & $47.08 \pm 0.32$ & $13.03 \pm 0.51$ & $0.38 \pm 0.03$ & $0.01 \pm 0.01$ & $0.82 \pm 0.17$ & $6.04 \pm 0.86$ & $0.05 \pm 0.01$ & $13.12 \pm 0.38$ & 14.36 \\
\hline & & $1 \mathrm{M}$ & $50.12 \pm 0.62$ & $12.87 \pm 0.33$ & $0.33 \pm 0.05$ & $0.01 \pm 0.01$ & $0.78 \pm 0.19$ & $5.96 \pm 0.54$ & $0.04 \pm 0.01$ & $10.14 \pm 0.41$ & 15.35 \\
\hline & & $2 \mathrm{M}$ & $52.14 \pm 0.85$ & $11.86 \pm 0.40$ & $0.28 \pm 0.01$ & ND & $0.72 \pm 0.22$ & $5.82 \pm 0.33$ & $0.02 \pm 0.01$ & $8.54 \pm 0.31$ & 16.45 \\
\hline & \multirow[t]{6}{*}{ Kimathi } & $0.0 \mathrm{M}$ & $55.40 \pm 0.20$ & $22.40 \pm 0.02$ & $0.67 \pm 0.05$ & $1.82 \pm 0.02$ & $2.65 \pm 0.03$ & $0.62 \pm 0.03$ & $0.06 \pm 0.02$ & $3.90 \pm 0.02$ & 12.2 \\
\hline & & $0.1 \mathrm{M}$ & $56.46 \pm 0.83$ & $21.37 \pm 0.37$ & $0.65 \pm 0.06$ & $1.8 \pm 0.05$ & $2.45 \pm 0.04$ & $0.61 \pm 0.08$ & $0.05 \pm 0.02$ & $3.85 \pm 0.52$ & 13.11 \\
\hline & & $0.25 \mathrm{M}$ & $58.16 \pm 0.73$ & $20.89 \pm 0.54$ & $0.62 \pm 0.05$ & $1.66 \pm 0.03$ & $2.39 \pm 0.03$ & $0.58 \pm 0.04$ & $0.04 \pm 0.01$ & $3.78 \pm 0.48$ & 13.98 \\
\hline & & $0.5 \mathrm{M}$ & $61.04 \pm 0.63$ & $18.87 \pm 0.09$ & $0.6 \pm 0.04$ & $1.57 \pm 0.02$ & $2.29 \pm 0.02$ & $0.51 \pm 0.02$ & $0.03 \pm 0.01$ & $3.66 \pm 0.08$ & 14.16 \\
\hline & & $1 \mathrm{M}$ & $63.14 \pm 0.47$ & $18.14 \pm 0.08$ & $0.54 \pm 0.02$ & $1.5 \pm 0.04$ & $2.21 \pm 0.01$ & $0.48 \pm 0.06$ & $0.03 \pm 0.01$ & $3.61 \pm 0.04$ & 14.98 \\
\hline & & $2 \mathrm{M}$ & $65.16 \pm 0.76$ & $17.45 \pm 0.07$ & $0.45 \pm 0.02$ & $1.43 \pm 0.02$ & $2.16 \pm 0.01$ & $0.43 \pm 0.04$ & $0.02 \pm 0.01$ & $3.57 \pm 0.05$ & 15.02 \\
\hline & \multirow[t]{6}{*}{ Ithanje } & $0.0 \mathrm{M}$ & $44.03 \pm 0.03$ & $30.33 \pm 0.15$ & $0.53 \pm 0.03$ & $0.02 \pm 0.01$ & $0.84 \pm 0.02$ & $3.49 \pm 0.03$ & $0.23 \pm 0.15$ & $10.40 \pm 0.20$ & 10.84 \\
\hline & & $0.1 \mathrm{M}$ & $46.05 \pm 0.59$ & $29.09 \pm 0.24$ & $0.51 \pm 0.06$ & $0.02 \pm 0.01$ & $0.81 \pm 0.07$ & $3.42 \pm 0.11$ & $0.21 \pm 0.03$ & $10.13 \pm 0.32$ & 10.98 \\
\hline & & $0.25 \mathrm{M}$ & $52.92 \pm 0.69$ & $28.12 \pm 0.46$ & $0.42 \pm 0.08$ & $0.02 \pm 0.01$ & $0.77 \pm 0.04$ & $3.36 \pm 0.08$ & $0.17 \pm 0.04$ & $9.98 \pm 0.25$ & 11.06 \\
\hline & & $0.5 \mathrm{M}$ & $54.18 \pm 0.58$ & $26.16 \pm 0.64$ & $0.33 \pm 0.05$ & $0.01 \pm 0.01$ & $0.72 \pm 0.06$ & $3.27 \pm 0.06$ & $0.14 \pm 0.03$ & $8.45 \pm 0.81$ & 11.99 \\
\hline & & $1 \mathrm{M}$ & $55.87 \pm 0.38$ & $25.13 \pm 0.18$ & $0.27 \pm 0.03$ & ND & $0.68 \pm 0.02$ & $3.22 \pm 0.04$ & $0.12 \pm 0.02$ & $8.41 \pm 0.63$ & 12.47 \\
\hline & & $2 \mathrm{M}$ & $59.45 \pm 0.26$ & $21.35 \pm 0.34$ & $0.22 \pm 0.01$ & ND & $0.63 \pm 0.02$ & $3.16 \pm 0.02$ & $0.09 \pm 0.01$ & $7.42 \pm 0.15$ & 13.87 \\
\hline \multirow{18}{*}{$\begin{array}{l}\text { Oxalic } \\
\text { acid }\end{array}$} & \multirow[t]{6}{*}{ Githima } & $0.0 \mathrm{M}$ & $40.80 \pm 0.06$ & $16.27 \pm 0.05$ & $0.56 \pm 0.04$ & $0.02 \pm 0.01$ & $0.96 \pm 0.03$ & $7.62 \pm 0.03$ & $0.08 \pm 0.02$ & $20.53 \pm 0.15$ & 11.47 \\
\hline & & $0.1 \mathrm{M}$ & $47.06 \pm 0.73$ & $14 \pm 0.16$ & $0.52 \pm 0.06$ & $0.02 \pm 0.01$ & $0.92 \pm 0.01$ & $7.42 \pm 0.56$ & $0.07 \pm 0.02$ & $15 \pm 0.57$ & 13.00 \\
\hline & & $0.25 \mathrm{M}$ & $50.46 \pm 0.58$ & $12.42 \pm 0.09$ & $0.41 \pm 0.03$ & $0.01 \pm 0.01$ & $0.72 \pm 0.06$ & $7.31 \pm 0.52$ & $0.05 \pm 0.02$ & $9.16 \pm 0.52$ & 16.18 \\
\hline & & $0.5 \mathrm{M}$ & $54 \pm 0.38$ & $10 \pm 0.39$ & $0.39 \pm 0.04$ & $0.01 \pm 0.01$ & $0.32 \pm 0.07$ & $7.24 \pm 0.34$ & $0.03 \pm 0.01$ & $8.2 \pm 0.67$ & 17.62 \\
\hline & & $1 \mathrm{M}$ & $56 \pm 0.45$ & $9.04 \pm 0.21$ & $0.32 \pm 0.08$ & ND & $0.27 \pm 0.03$ & $7.21 \pm 0.59$ & $0.02 \pm 0.01$ & $8.01 \pm 0.89$ & 19.04 \\
\hline & & $2 \mathrm{M}$ & $59.02 \pm 0.32$ & $7.16 \pm 0.52$ & $0.28 \pm 0.04$ & ND & $0.24 \pm 0.02$ & $7.16 \pm 0.65$ & $0.01 \pm 0.01$ & $7.56 \pm 0.92$ & 20.42 \\
\hline & \multirow[t]{6}{*}{ Kimathi } & $0.0 \mathrm{M}$ & $55.40 \pm 0.20$ & $22.40 \pm 0.02$ & $0.67 \pm 0.05$ & $1.82 \pm 0.02$ & $2.65 \pm 0.03$ & $0.62 \pm 0.03$ & $0.06 \pm 0.02$ & $3.90 \pm 0.02$ & 12.2 \\
\hline & & $0.1 \mathrm{M}$ & $56.02 \pm 0.84$ & $19.62 \pm 0.48$ & $0.62 \pm 0.08$ & $1.42 \pm 0.08$ & $2.34 \pm 0.05$ & $0.44 \pm 0.04$ & $0.05 \pm 0.02$ & $3.62 \pm 0.08$ & 13.02 \\
\hline & & $0.25 \mathrm{M}$ & $57.02 \pm 0.63$ & $18.04 \pm 0.42$ & $0.58 \pm 0.06$ & $1.12 \pm 0.04$ & $2.1 \pm 0.04$ & $0.42 \pm 0.03$ & $0.04 \pm 0.01$ & $3.11 \pm 0.07$ & 14.12 \\
\hline & & $0.5 \mathrm{M}$ & $61.11 \pm 0.83$ & $15.54 \pm 0.27$ & $0.54 \pm 0.03$ & $0.84 \pm 0.05$ & $1.96 \pm 0.06$ & $0.4 \pm 0.01$ & $0.02 \pm 0.01$ & $2.84 \pm 0.04$ & 16.02 \\
\hline & & $1 \mathrm{M}$ & $63.07 \pm 0.45$ & $13.08 \pm 0.09$ & $0.51 \pm 0.03$ & $0.78 \pm 0.03$ & $1.92 \pm 0.02$ & $0.37 \pm 0.02$ & $0.01 \pm 0.01$ & $2.81 \pm 0.03$ & 17.72 \\
\hline & & $2 \mathrm{M}$ & $65 \pm 0.55$ & $12.92 \pm 0.28$ & $0.46 \pm 0.04$ & $0.73 \pm 0.03$ & $1.88 \pm 0.04$ & $0.33 \pm 0.03$ & $0.01 \pm 0.01$ & $2.77 \pm 0.05$ & 18.02 \\
\hline & \multirow[t]{6}{*}{ Ithanje } & $0.0 \mathrm{M}$ & $44.03 \pm 0.03$ & $30.33 \pm 0.15$ & $0.53 \pm 0.03$ & $0.02 \pm 0.01$ & $0.84 \pm 0.02$ & $3.49 \pm 0.03$ & $0.23 \pm 0.15$ & $10.40 \pm 0.20$ & 10.84 \\
\hline & & $0.1 \mathrm{M}$ & $45.02 \pm 0.53$ & $24.96 \pm 0.28$ & $0.41 \pm 0.08$ & $0.02 \pm 0.01$ & $0.83 \pm 0.07$ & $2.84 \pm 0.09$ & $0.09 \pm 0.03$ & $9.94 \pm 0.52$ & 15.02 \\
\hline & & $0.25 \mathrm{M}$ & $46.22 \pm 0.41$ & $22.92 \pm 0.36$ & $0.33 \pm 0.06$ & $0.02 \pm 0.01$ & $0.82 \pm 0.03$ & $2.83 \pm 0.06$ & $0.07 \pm 0.02$ & $9.12 \pm 0.62$ & 16.41 \\
\hline & & $0.5 \mathrm{M}$ & $47.91 \pm 0.38$ & $20.66 \pm 0.52$ & $0.27 \pm 0.01$ & $0.01 \pm 0.01$ & $0.72 \pm 0.06$ & $2.8 \pm 0.04$ & $0.04 \pm 0.02$ & $8.02 \pm 0.48$ & 19.83 \\
\hline & & $1 \mathrm{M}$ & $48.34 \pm 0.66$ & $17.09 \pm 0.22$ & $0.21 \pm 0.04$ & $0.01 \pm 0.01$ & $0.68 \pm 0.03$ & $2.75 \pm 0.01$ & $0.03 \pm 0.01$ & $7.95 \pm 0.64$ & 20.04 \\
\hline & & $2 \mathrm{M}$ & $49.42 \pm 0.32$ & $14.78 \pm 0.08$ & $0.18 \pm 0.04$ & ND & $0.62 \pm 0.02$ & $2.71 \pm 0.08$ & $0.02 \pm 0.01$ & $7.91 \pm 0.78$ & 20.98 \\
\hline
\end{tabular}

\section{*Values are means \pm SD $(n=3)$}

The $\mathrm{SiO}_{2}$ content of Githima clay increased from 40.80 to $52.14 \%$ as $\mathrm{HCl}$ acid strength increased from $0.0 \mathrm{M}$ to $2 \mathrm{M}$. However, silica $\left(\mathrm{SiO}_{2}\right)$ content for the Githima sample treated with $\mathrm{HCl}$ acid fall within the standard range of $46-62 \% \mathrm{SiO}_{2}$ content that is required for the production of good refractory materials [19]. LOI increased as well from $11.47 \%$ to $16.45 \%$ as $\mathrm{HCl}$ acid strength increased from $0.0 \mathrm{M}$ to $2 \mathrm{M}$, LOI values for all Githima sample treated clays were within the acceptable range of 8-18\% LOI for refractory bricks [20]. Alumina composition in Githima sample treated with $\mathrm{HCl}$ decreased from $16.27 \%$ to $11.86 \%$ as $\mathrm{HCl}$ acid concentration increased from $0.0 \mathrm{M}$ to $2 \mathrm{M}$. However, the values of alumina $\left(\mathrm{Al}_{2} \mathrm{O}_{3}\right)$ content did not meet the requirement of $25-44 \% \mathrm{Al}_{2} \mathrm{O}_{3}$ for refractory bricks [20]. The composition of iron oxides in Githima sample treated with $\mathrm{HCl}$ decreased from $20.53 \%$ to $8.54 \%$ as acid concentration increased from $0.0 \mathrm{M}$ to $2 \mathrm{M}$. However, all the samples treated with $\mathrm{HCl}$ have higher iron content that did not fall within the standard range of 0.5-2.4 \% $\mathrm{Fe}_{2} \mathrm{O}_{3}$ for refractory bricks [20]. Magnesium oxide $(\mathrm{MgO})$ content decreased with an increase in $\mathrm{HCl}$ acid concentration $(0.0 \mathrm{M}$ to $2 \mathrm{M})$ from 0.02 to below detectable levels. Potassium oxide $\left(\mathrm{K}_{2} \mathrm{O}\right)$ content decreased from 0.96 to $0.72 \%$ as acid strength increased from $0.0 \mathrm{M}$ to $2 \mathrm{M} \mathrm{HCl}$. Titanium oxide $\left(\mathrm{TiO}_{2}\right)$ content decreased from 7.62 to $5.82 \%$ as acid strength increased from $0.0 \mathrm{M}$ to $2 \mathrm{M} \mathrm{HCl}$. Manganese oxide $(\mathrm{MnO})$ content decreased from 0.08 to $0.01 \%$ as acid strength increased from $0.0 \mathrm{M}$ to $2 \mathrm{M}$. It is clear from the results in Table 1 above that as the acid strength increased from $0.0 \mathrm{M}$ to $2 \mathrm{M}$, 
the levels of $\mathrm{MgO}, \mathrm{Al}_{2} \mathrm{O}_{3}, \mathrm{CaO}, \mathrm{K}_{2} \mathrm{O}$, and $\mathrm{TiO}_{2}$ decreased progressively. However, the levels of $\mathrm{SiO}_{2}$ and $\mathrm{LOI}$ increased as acid strength increased. This is in line with a report by Panda et al., [21] while studying the effect of acid treatment on Kaolin clay structure and chemical properties [21].

The silica content in the Githima clay sample treated with oxalic acid increased from $40.80 \%$ to $59.02 \%$ as the acid concentration increased from $0.0 \mathrm{M}$ to $2 \mathrm{M}$. However, all the values of the Githima sample treated with oxalic acid fall within the standard range of 46-62\% $\mathrm{SiO}_{2}$ content that is required for the production of good refractory materials [19]. LOI values of Githima samples treated with oxalic acid increased from $11.47 \%$ to $20.42 \%$ as the acid concentration increased from $0.0 \mathrm{M}$ to $2 \mathrm{M}$. However, most of the LOI values for Githima samples treated with oxalic acid are within the standard range of 8-18\% LOI for refractory bricks [20]. The composition of iron oxide content decreases from 20.53 to $7.56 \%$ with an increase in oxalic acid concentration from $0.0 \mathrm{M}$ to $2 \mathrm{M}$. However, iron oxides content was high and did not fall within the acceptable range of 0.5-2.4 \% $\mathrm{Fe}_{2} \mathrm{O}_{3}$ for refractory bricks [20]. The composition of alumina $\left(\mathrm{Al}_{2} \mathrm{O}_{3}\right)$ as well decreased from 16.27 to $7.16 \%$ as oxalic acid concentration increased from $0.0 \mathrm{M}$ to $2 \mathrm{M}$. However, alumina content for all the samples is below the acceptable range of 25-44 \% $\mathrm{Al}_{2} \mathrm{O}_{3}$ for refractory bricks [20]. Titanium oxide $\left(\mathrm{TiO}_{2}\right)$ levels decreased from 7.62 to $7.16 \%$ as oxalic acid concentration increased from $0.0 \mathrm{M}$ to $2 \mathrm{M}$. Potassium oxide $\left(\mathrm{K}_{2} \mathrm{O}\right)$ content reduced from 0.96 to $0.24 \%$ as oxalic acid concentration increased from $0.0 \mathrm{M}$ to $2 \mathrm{M}$. Manganese oxide $(\mathrm{MnO})$ content reduced from 0.08 to $0.01 \%$ as oxalic acid concentration increased from $0.0 \mathrm{M}$ to $2 \mathrm{M}$. Magnesium oxide $(\mathrm{MgO})$ content was reduced from $0.02 \%$ to below detectable levels. Calcium oxide $(\mathrm{CaO})$ content was reduced from 0.52 to $0.28 \%$. From the results in Table 1 above it is clear that the elemental composition of Githima clay is significantly affected with acid treatment (oxalic acid), the levels of $\mathrm{SiO}_{2}$ and $\mathrm{LOI}$ increase as oxalic acid concentration increases. However, $\mathrm{Fe}_{2} \mathrm{O}_{3}, \mathrm{Al}_{2} \mathrm{O}_{3}, \mathrm{MgO}, \mathrm{CaO}, \mathrm{MnO}, \mathrm{TiO}_{2}$, and $\mathrm{K}_{2} \mathrm{O}$ decrease with an increase in oxalic acid concentration.

The $\mathrm{SiO}_{2}$ content of the Kimathi sample treated with $\mathrm{HCl}$ increased from 55.40 to $65.16 \%$ as acid concentration increased from $0.0 \mathrm{M}$ to $2 \mathrm{M} \mathrm{HCl}$. However, most of the $\mathrm{SiO}_{2}$ values fall within the acceptable range of 46-62\% for the production of good refractory materials [19]. LOI of the Kimathi sample treated with $\mathrm{HCl}$ increased as well from 12.20 to $15.02 \%$ as acid concentration increased from $0.0 \mathrm{M}$ to $2 \mathrm{M} \mathrm{HCl}$. However, all LOI values for Kimathi acid-treated samples were within the standard range of 8-18\% LOI for refractory bricks [20]. The composition of iron oxides $\left(\mathrm{Fe}_{2} \mathrm{O}_{3}\right)$ content decreased progressively from 3.90 to $3.57 \%$ as acid concentration increased from $0.0 \mathrm{M}$ to $2 \mathrm{M} \mathrm{HCl}$. However, iron oxides content was high and therefore did not fall within the standard range of 0.5-2.4\% $\mathrm{Fe}_{2} \mathrm{O}_{3}$ for refractory bricks [20]. The composition of alumina $\left(\mathrm{Al}_{2} \mathrm{O}_{3}\right)$ was reduced significantly from $22.40 \%$ to $17.45 \%$ as $\mathrm{HCl}$ concentration increased from $0.0 \mathrm{M}$ to $2 \mathrm{M}$. However, no alumina $\left(\mathrm{Al}_{2} \mathrm{O}_{3}\right)$ content values fall within the standard range of 25-44\% $\mathrm{Al}_{2} \mathrm{O}_{3}$ for refractory bricks [20] (Chester, 1973). Potassium oxide $\left(\mathrm{K}_{2} \mathrm{O}\right)$ content was reduced from 2.65 to $2.16 \%$ as $\mathrm{HCl}$ concentration increased from $0.0 \mathrm{M}$ to 2M. Magnesium oxide (MgO) content decreased as well from 1.82 to $1.43 \%$ as $\mathrm{HCl}$ concentration increased from $0.0 \mathrm{M}$ to $2 \mathrm{M}$. Calcium oxide $(\mathrm{CaO})$ content decreased from 0.67 to $0.45 \%$ as $\mathrm{HCl}$ concentration increased from $0.0 \mathrm{M}$ to $2 \mathrm{M}$. Titanium oxide $\left(\mathrm{TiO}_{2}\right)$ content decreased from 0.62 to $0.43 \%$ as $\mathrm{HCl}$ concentration increased from $0.0 \mathrm{M}$ to $2 \mathrm{M}$. Manganese oxide $(\mathrm{MnO})$ content decreased from 0.06 to $0.02 \%$ as $\mathrm{HCl}$ concentration increased from $0.0 \mathrm{M}$ to $2 \mathrm{M}$. From Table 1 above, it is evident that Kimathi clay elemental composition is affected by treating with hydrochloric acid. The levels of most soluble metal oxides decreased with an increase in the concentration of the acid. Levels of $\mathrm{Al}_{2} \mathrm{O}_{3}, \mathrm{CaO}, \mathrm{MgO}, \mathrm{K}_{2} \mathrm{O}, \mathrm{TiO}_{2}, \mathrm{MnO}$, and $\mathrm{Fe}_{2} \mathrm{O}_{3}$ decreased progressively with an increase in $\mathrm{HCl}$ concentration. These findings are in agreement with findings by Eze et al., [3] while investigating the effect of acid treatment on the physicochemical properties of Kaolin clay obtained from a mine in Abia state, Nigeria [3].

The silica content of Kimathi clay increased from 55.40 to $65.00 \%$ as oxalic acid concentration increases from $0.0 \mathrm{M}$ to $2 \mathrm{M}$. However, most of the silica content values fall within the standard range of $46-62 \%$ for refractory bricks [19]. Loss On Ignition (LOI) increased as well from 12.20 to $18.02 \%$ with an increase in oxalic acid concentration from $0.0 \mathrm{M}$ to $2 \mathrm{M}$. However, most of the LOI values fall within the standard range of $8-18 \%$ LOI for refractory bricks. The composition of iron oxide $\left(\mathrm{Fe}_{2} \mathrm{O}_{3}\right)$ reduced from 3.90 to $2.77 \%$ as oxalic acid concentration increased from $0.0 \mathrm{M}$ to $2 \mathrm{M}$. However, iron content values are higher than the recommended range of $0.5-2.4 \% \mathrm{Fe}_{2} \mathrm{O}_{3}$ for refractory bricks [20]. Alumina $\left(\mathrm{Al}_{2} \mathrm{O}_{3}\right)$ content decreased from 22.40 to $12.92 \%$ as oxalic acid concentration increased from $0.0 \mathrm{M}$ to $2 \mathrm{M}$. However, alumina composition does not fall within the recommended range of 25-44\% for refractory bricks [20]. Potassium oxide $\left(\mathrm{K}_{2} \mathrm{O}\right)$ content decreased from 2.65 to $1.88 \%$ as oxalic acid concentration increased. Magnesium oxide $(\mathrm{MgO})$ content was reduced from 1.82 to $0.73 \%$. Manganese oxide $(\mathrm{MnO})$ was reduced as well from 0.06 to $0.01 \%$. Titanium oxide $\left(\mathrm{TiO}_{2}\right)$ was reduced from 0.62 to $0.33 \%$. Generally, most of the metallic oxides in Kimathi clay samples are leached with oxalic acid, some of those oxides include $\mathrm{Fe}_{2} \mathrm{O}_{3}, \mathrm{Al}_{2} \mathrm{O}_{3}, \mathrm{MnO}, \mathrm{CaO}, \mathrm{K} 2 \mathrm{O}, \mathrm{MgO}$ and $\mathrm{TiO}_{2}$, these oxides decreases with increase in oxalic acid concentration. However, $\mathrm{SiO}_{2}$ and LOI levels increase with an increase in acid strength.

The composition of silica $\left(\mathrm{SiO}_{2}\right)$ increased from 44.03 to $59.45 \%$ as $\mathrm{HCl}$ concentration increased from $0.0 \mathrm{M}$ to $2 \mathrm{M}$. However, most silica composition values fall within the recommended range of $46-62 \% \mathrm{SiO}_{2}$ for the production of good refractory materials [19]. Loss On Ignition (LOI) increased as well from 10.84 to $13.87 \%$ as Hydrochloric $(\mathrm{HCl})$ acid concentration increased from $0.0 \mathrm{M}$ to $2 \mathrm{M}$. However, all LOI values fall within the 
acceptable range of 8-18\% LOI for refractory bricks [20]. Iron oxide $\left(\mathrm{Fe}_{2} \mathrm{O}_{3}\right)$ composition decreased from 10.84 to $7.42 \%$ as $\mathrm{HCl}$ concentration increased from $0.0 \mathrm{M}$ to $2 \mathrm{M}$. However, iron oxide content does not fall within the acceptable range of $0.5-2.4 \%$ for refractory bricks [20]. Alumina $\left(\mathrm{Al}_{2} \mathrm{O}_{3}\right)$ was reduced from 30.33 to $21.35 \%$ with hydrochloric $(\mathrm{HCl})$ acid increase from $0.0 \mathrm{M}$ to $2 \mathrm{M}$. However, most of the alumina content values fall within the acceptable range of 25-44 \% $\mathrm{Al}_{2} \mathrm{O}_{3}$ for refractory bricks [20](Chester, 1973). Titanium oxide $\left(\mathrm{TiO}_{2}\right)$ was reduced from 3.42 to $3.16 \%$ as $\mathrm{HCl}$ concentration increased from $0.0 \mathrm{M}$ to $2 \mathrm{M}$. Calcium oxide $(\mathrm{CaO})$ was reduced from 0.51 to $0.22 \%$ as $\mathrm{HCl}$ concentration increased from $0.0 \mathrm{M}$ to $2 \mathrm{M}$. Potassium oxide $\left(\mathrm{K}_{2} \mathrm{O}\right)$ decreased from 0.81 to $0.63 \%$ as $\mathrm{HCl}$ concentration increased from $0.0 \mathrm{M}$ to $2 \mathrm{M}$. Manganese oxide $(\mathrm{MgO})$ levels were reduced from 0.21 to $0.09 \%$ as hydrochloric acid $(\mathrm{HCl})$ concentration increased. Magnesium oxide $(\mathrm{MgO})$ levels were reduced from 0.02 to below detectable levels. Elemental composition of clays from Ithanje was significantly affected with treatment with hydrochloric acid, levels of $\mathrm{SiO}_{2}$, and LOI increased with an increase in $\mathrm{HCl}$ concentration as shown in Table 1 above. However, some of the metallic oxides were reduced by $\mathrm{HCl}$ treatment, metallic oxides decreased by acid treatment include; $\mathrm{Fe}_{2} \mathrm{O}_{3}, \mathrm{Al}_{2} \mathrm{O}_{3}, \mathrm{MnO}, \mathrm{K}_{2} \mathrm{O}, \mathrm{MgO}$ and $\mathrm{CaO}$. These results are similar to one found by Xavier et al., [8] while investigating the effect of acid treatment on clay palygorskite clay obtained from Guadalupe[8].

The composition of silica increased from 44.03 to $49.42 \%$ as oxalic acid concentration increased from $0.0 \mathrm{M}$ to $2 \mathrm{M}$. However, most silica content values fall within the recommended range of $46-62 \% \mathrm{SiO}_{2}$ for the production of good refractory materials [19]. Loss On Ignition (LOI) increased as well from 10.84 to $20.98 \%$ as oxalic acid concentration increased from $0.0 \mathrm{M}$ to $2 \mathrm{M}$. However, most of the LOI values fall within the acceptable range of 8$18 \% \mathrm{Al}_{2} \mathrm{O}_{3}$ for refractory bricks [20]. Alumina $\left(\mathrm{Al}_{2} \mathrm{O}_{3}\right)$ composition decreased from 30.33 to $14.78 \%$ as oxalic acid concentration increased from $0.0 \mathrm{M}$ to $2 \mathrm{M}$. However, most of the alumina content values fall within the acceptable range of $25-44 \% \mathrm{Al}_{2} \mathrm{O}_{3}$ for refractory bricks [20]. Iron oxide $\left(\mathrm{Fe}_{2} \mathrm{O}_{3}\right)$ composition reduced from 10.40 to $7.91 \%$ as oxalic acid concentration increased from $0.0 \mathrm{M}$ to $2 \mathrm{M}$. Titanium oxide $\left(\mathrm{TiO}_{2}\right)$ content decreased from 3.49 to $2.71 \%$ as oxalic acid concentration increased from $0.0 \mathrm{M}$ to $2 \mathrm{M}$. Potassium oxide $\left(\mathrm{K}_{2} \mathrm{O}\right)$ content decreased from 0.84 to $0.62 \%$ as oxalic acid concentration increased from $0.0 \mathrm{M}$ to $2 \mathrm{M}$. Manganese oxide (MnO) content decreased as well from 0.14 to $0.02 \%$ as oxalic acid concentration increased from $0.0 \mathrm{M}$ to $2 \mathrm{M}$. Magnesium oxide $(\mathrm{MgO})$ was reduced from $0.02 \%$ to below detectable levels. Treating Ithanje clay samples with oxalic acid shows that some of its metallic oxides are adversely affected. From the results, it is evident that oxalic acid leached some of the soluble metallic oxides such as $\mathrm{Fe}_{2} \mathrm{O}_{3}, \mathrm{Al}_{2} \mathrm{O}_{3}, \mathrm{MgO}, \mathrm{CaO}$, and $\mathrm{TiO}_{2}$; their levels were reduced with increase in acid strength. However, $\mathrm{SiO}_{2}$ and LOI levels increased with an increase in acid strength.

The results of acid treatment indicate that the chemical composition of the clays changed substantially. As the concentration of the acid increased, there was a marked increase in the dissolution of all soluble cations [8]. The acid treatment causes a reduction in the composition of most elements with a higher reduction being achieved at a higher concentration as shown in Table 1 above. Wachira, [14] did a study on effects of acids (sulphuric, hydrochloric and oxalic acid) treatment on the iron composition of clays from Murkurwe-ini and found that the levels of $\mathrm{SiO}_{2}$ and LOI increased after acid treatment while there was a reduction of $\mathrm{Fe}_{2} \mathrm{O}_{3}, \mathrm{MgO}, \mathrm{Na}_{2} \mathrm{O}, \mathrm{Al}_{2} \mathrm{O}_{3}$, $\mathrm{TiO}_{2}$, and $\mathrm{CaO}$, these findings are in agreement with the results in Table 1 [14].

Loss On Ignition (LOI) of the clays increased after acid treatment. This is due to an increase of amorphous silica that made water adsorption higher [21].

Figure 1 below gives a more simplified but comprehensive summary of the comparison of iron removal from the clay samples from the selected sites between the two acids (hydrochloric and oxalic acid). Oxalic acid was found to be more effective at the same acid concentration than hydrochloric acid and this was in agreement with the previous report by Calderon et al., [18]. The findings were in line with the report by Wachira [14] while studying iron removal of clays and restoration of clays' plasticity [14]. 


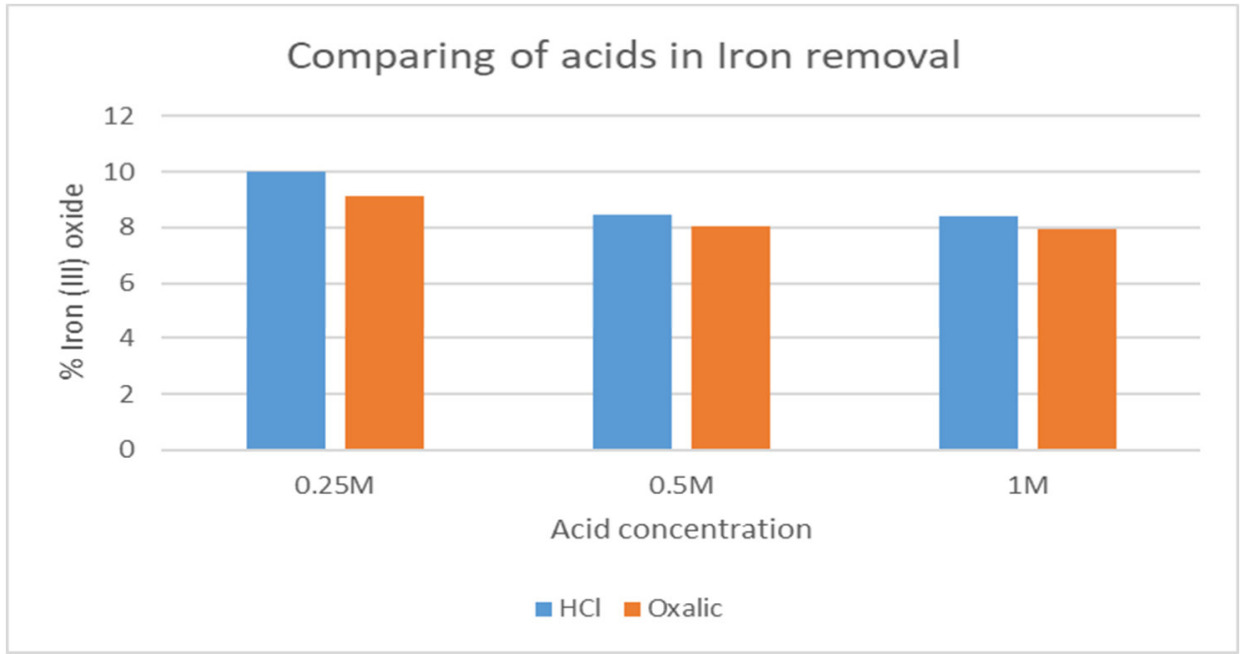

Figure 1: Comparison of the effect of acids treatment on the iron composition of clay sample

Results of the elemental composition of clays from the three selected sites (Table 1 above) show that the clays are affected significantly by acid treatment, therefore this justifies the hypothesis that the elemental composition of clays from selected sites in Murang'a and Nyeri counties are affected by acid treatment.

\section{Conclusion}

From the results, it is evident that hydrochloric and oxalic acid removes impurities such as iron oxides from clays by the dissolution of metallic compounds having deleterious effects on applications of clays. Increasing the acid concentration from $0.0 \mathrm{M}$ to $2 \mathrm{M} \mathrm{HCl}$ increases the acid attack on the clay structure which results in more bond breaking and the formation and subsequently, more metallic oxides are leached from clay.

This study has also established that the quality of the clay is noticeably improved by acid treatment by reducing its iron content and other metallic oxides having a negative effect on clay applications for industrial materials. Clays with iron content less than $1 \%$ find applications in high-grade ceramics, paper industry, catalysis, filler material, and on white cement.

Acid treatment can be used to improve properties of clays from Githima, Kimathi, and Ithanje hence the clays can be used as a source of raw materials for industrial applications.

\section{Acknowledgement}

My gratitude goes to the staff at the department of Physical and Biological Sciences of Murang'a University of Technology for constructive critique and corrective interactions, which directed the work to successful completion. My appreciations also go to the management and technical staff at the Ministry of Petroleum and Mining, Geology and Mines Department for support during the laboratory analysis of the samples.

\section{References}

[1] Deer, W. A.; Howie, R. A.; Zussman, J., (1992). An introduction to Rock Forming Minerals, Harlow longman.

[2] Murray, H. H., (2004). Kirk-Othmer, Encyclopaedia of Chemical Technology, $5^{\text {th }}$ ed., John Willey and Sons, England, 6: 650-750.

[3] Eze, K. A.; Nwadiogbu, J. O.; Nwankere, E. T., (2012). Effect of acid treatment on the physiochemical properties of Kaolin clay. Archives of Applied Science Research, 4(2): 792-794.

[4]Caulcante, A. M.; Torres, L. G.; Welho, G. L. V., (2005). Effect of acid treatments on the Physicochemical Properties of Kaolin Clay. Brazilian Journal of Chemical Engineering, 22: 2682-2865.

[5] Belver, C.; Munor, M. A.; Vicente, M. A., (2002). Chemical activation of a Kaolinite Under acid and alkaline condition. Chemistry of Materials, 14: 2033-2043.

[6] Vaga, G., (2007).Effect of Acid Treatment on Physicochemical Properties of Kaolin Clay. Epitoanyag, 59, 48.

[7] Salawudeen, T, O.; Dada, E. O.; Alagbe, S. O., (2007). Journal of Engineering and Applied Sciences, 2, 11, $1677-1680$

[8] Xavier, K. C. M.; Santos, M. D. S .F.; Santos, M. R. M .C.; Oliveira, M. E. R.; Carvalho, M. W. N. C; Osajima, J. A; Edson, C. D. S. F., (2014). Effects of Acid Treatment on the Clay Palygorskite: XRD, surface area, morphological and chemical composition. Materials Research. 17: 3-8.

[9] Karoki, B. K. (2009). Analysis and treatment of clays from Mwea to assess their value as a source of Aluminium and Ceramic products (Doctoral dissertation).

[11] Ajayi, O. A.; Adefila, S. S., (2012). Comparative Study of Chemical and Biological Methods of Beneficiation 
of Kankara Kaolin. International Journal of Scientific and Technology Research, 1(8): 13-18.

[12] Ajemba, R. O., (2016). Structural Alteration of Bentonite from Nkaliki by Acid Treatment: Studies of the Kinetics and properties of the Modified samples. International Journal of Advances in Engineering and Technology.7:379-392.

[13] Muriithi, N. T.; Karoki, K. B.; Gachanja, A. N., (2012), Chemical and mineral analyses of Mwea Clays, International Journal of Physical Sciences, 17: 44.

[14]Mutembei, P. K.; Muthengia, J. W.; Muriithi, N. T., (2013). Iron enrichment in laterites soils from selected regions in Kenya using magnetic separation. IOSR Journal of Engineering, 4(3), 42-48.

[15] Wachira, D. M., (2014). Iron removal from clays by acid treatment and reversal of the clay's plasticity, Masters Thesis, Department of chemistry, Kenyatta university, Kenya (unpublished).

[16] Oswago, M. O., (2016). Chemical and mineral analysis of raw and acid-treated clays from Kano plains, Kisumu Counties, Kenya, Master of Science un-published, Kenyatta university, Kenya.

[17] Coma, A.; Misfud, A.; Sanz, E., (1990). Clay Minerals and their Admixtures. Scientific Publishing Company, New York., Clay minerals, 19: 25.

[18] Al-Zahrani, A.; Abdul-Majid, M. (2009). Extraction of alumina from local clays by hydrochloric acid process. Journal of Engineering Science, 20(2): 29-41.

[19] Calderon, D.; Martinez, M.; Mendez, O.; Rodriguez, J., (2005). Iron leaching of Mexican clay of Industrial interest by Oxalic Acid. The AZO Journal of Materials online, 1(2005) (ISSN 1833-122X) DOI: 10.2240/azojomo0168.

[20] Chester, J. H., (1973). Refractories, production and properties. Iron and steel institute, London.

[21] Yami, A. M., and Umaru, S., (2007). Characterization of some Nigerian clays as refractory materials for furnace lining. Continental Journal of Engineering Sciences, 30-35, C Wilolud online journals.

[22] Panda, A. K., Raju, M. V. L. N., Rao, S. V., Lavanya, G., Reddy, E., \& Sunder, G. S. (2010). Replacement of normal maize with quality protein maize on performance, immune response and carcass characteristics of broiler chickens. Asian-Australasian Journal of Animal Sciences, 23(12), 1626-1631. 